\title{
Analisis Asas dan Tujuan dari Undang-Undang Kelautan, serta Peran Keilmuan Geodesi dan Geomatika dalam Implementasinya di Indonesia
}

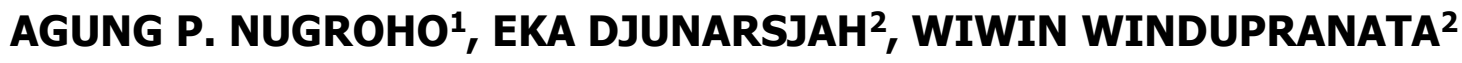 \\ ${ }^{1}$ Program Studi Teknik Geomatika, Jurusan Teknologi dan Infrastruktur \\ Kewilayahan, ITERA, Lampung Selatan \\ 2 Program Studi Teknik Geodesi dan Geomatika - FITB \\ Institut Teknologi Bandung \\ Email: agung@gt.itera.ac.id
}

\begin{abstract}
ABSTRAK
Wilayah dan potensi kelautan yang besar di Negara Kesatuan Republik Indonesia (NKRI) memerlukan pengelolaan yang sesuai agar dapat terjaga dan termanfaatkan dengan baik. Penyusunan dan pengesahan undang-undang nomor 32 tahun 2014 tentang kelautan adalah suatu bentuk usaha yang dilakukan negara dalam menata dan mengatur ruang lautnya secara terpadu. Undang-undang kelautan di dalamnya mempunyai sebelas asas dan delapan tujuan. Asas dan tujuan tersebut berisi mimpi-mimpi besar di bidang kelautan Indonesia dan harapannya dapat dicapai melalui undangundang ini. Akan tetapi kenyataanya masih banyak pekerjaan yang harus dilakukan untuk mengimplementasikannya sehingga mencapai kondisi ideal yang diharapkan. Penelitian ini bertujuan mengetahui sejauh mana undang-undang dapat diimplementasikan melalui uji prasyarat hukum undang-undang. Hasilnya undang-undang kelautan memenuhi syarat sah dan absah, sehingga dapat diimplementasikan dari aspek muatan hukum tersebut. Sedangkan, hasil analisis SWOT dan semantik bahasa menunjukkan bahwa implementasi dari undang-undang kelautan masih jauh dari harapan. Harapan kedepannya dengan dibuatnya aturan-aturan pendukung dan diperbaikinya kinerja pemerintahan, maka implementasinya akan berjalan lebih baik. Peranan bidang geodesi dan geomatika dalam bidang kelautan sudah sampai dalam tahapan membantu berbagai permasalahan di bidang kelautan.
\end{abstract}

Kata kunci: undang-undang, kelautan, asas, tujuan, implementasi

\begin{abstract}
Large marine regions and potential in the Republic of Indonesia require appropriate management and maintainance. Drafting and legitimating of maritme law no. 32 in 2014 are government effort in maintining and organizing of Indonesia sea $n$ integrated manner. Maritime law has eleven principles and eight objectives contained within. The principles and objectives contain big dreams for Indonesian marine. These dreams hope can be achieved with the existence of this law. But in fact is still much work to be done in implementing such a big dream to reach the ideal situation. This research aims to determine in which extent legislation can be implemented and carried out to test the legal prerequisite legislation, and the result is marine legislation qualified from legitimate and legal test so that it can be implemented from the aspect of the legal aspect. While the SWOT and semantic analysis can be seen that the implementation of marine legislation is still far from expectations, expected in the future with the establishment of rules from the and improved performance of the government, the implementation will be better. For the geodesy and geomatics roles are already in the level helpin in the problems of marine field.
\end{abstract}

Keywords: law, principle, objective, implementation 
Agung P. Nugroho, Eka Djunarsjah, Wiwin Windupranata

\section{Pendahuluan}

Indonesia merupakan negara kepulauan yang seluruhnya terdiri atas kepulauan-kepulauan dan mencakup pulau-pulau besar dan kecil yang merupakan satu kesatuan wilayah, politik, ekonomi, sosial budaya, dan historis. Kedaulatan Indonesia sebagai negara kepulauan meliputi wilayah daratan dan perairan, termasuk ruang udara di atasnya serta dasar laut dan tanah di bawahnya, termasuk kekayaan alam yang terkandung di dalamnya (Pemerintah Indonesia, 2014). Laut di Indonesia memiliki potensi yang besar. Dalam sudut pandang sektor ekonomi, laut Indonesia memiliki potensi ekonomi mencapai Rp 7.200 triliun per tahun dan dapat memberikan kesempatan kerja sekitar 40 juta orang (Dahuri, 2015a). Potensi yang besar memiliki tantangan besar yang mengikutinya. Pengelolaan dan pemanfaatan potensi yang ada adalah salah satu tantangannya. Potensi ekonomi yang belum termanfaatkan tersebut dapat dilihat dari kontribusi sektor ekonomi kelautan yang hanya menyumbangkan sekitar 20 persen dari Produk Domestik Bruto (PDB) (Dahuri, 2015b). Dalam hal pengelolaan laut maraknya penangkapan ikan ilegal, tidak terlaporkan, dan tidak ter-regulasi atau illegal, unreported, and unregulated fishing (IUUF), pencemaran lingkungan, penyelundupan barang ilegal atau manusia, dan lain-lainnya menjadi permasalahan yang harus diselesaikan.

Penyusunan dan pengesahan Undang-Undang Nomor 32 Tahun 2014 tentang Kelautan adalah suatu bentuk usaha negara dalam menata dan mengatur ruang lautnya secara terpadu. Undang-undang ini memiliki sebelas asas sebagai dasar penyelengaraan kelautan yang terdiri dari asas keberlanjutan, konsistensi, keterpaduan, kepastian hukum, kemitraan, pemerataan, peran serta masyarakat, keterbukaan, desentralisasi, akuntabilitas, dan keadilan. Selain asas, penyelenggaraan kelautan juga memiliki delapan tujuan. Asas dan tujuan adalah representasi mimpi besar yang terkandung di dalam suatu undang-undang. Asas berperan sebagai dasar dan koridor yang berbentuk abstrak sehingga realisasinya terlihat secara implisit di dalam realisasi tujuan. Sedangkan tujuan lebih bersifat nyata dan terlihat bentuknya, sehingga dari kalimat dan kata-kata di dalamnya dapat terlihat tujuan akhir yang ingin dicapai dari suatu aturan atau undang-undang yang ada.

Dalam implementasinya, Indonesia yang menganut tradisi civil law di mana pembuatan peraturan utamanya oleh lembaga parlemen (legislator) yang mana pembangunan undangundang seringkali dipersempit maknanya hanya dalam konteks pembuatan. Banyak pihak yang mengganggap dan berorientasi bahwa membangun undang-undang hanya cukup dengan membuatnya. Sehingga, implementasi undang-undang tidaklah dianggap sebagai tangungjawab pembuatnya. Akibatnya, para 'legislator' dan 'regulator' membuat undangundang tanpa merasa perlu mempertimbangkan apakah aturan yang dibuatnya dapat diimplementasikan (ditegakkan) atau tidak (Asshiddiqie, 2005). Sehingga perlu dilakukan studi terkait implementasi undang-undang kelautan di Indonesia.

Metode yang digunakan untuk melakukan analisis asas dan tujuan undang-undang kelautan antara lain adalah dengan menggunakan metode semantik bahasa untuk mengetahui makna, kemudian merumuskan klasifikasi asas dan pencapaian tujuan (keadaan ideal) berdasarkan kalimat dan kata-kata yang digunakan dalam asas dan tujuan tersebut. Metode analisis lain yang digunakan untuk mengetahui sejauh mana undang-undang dapat diimplementasikan adalah dengan yuridis normatif, salah satunya dengan melihat apakah undang-undang sudah memenuhi prasyarat penegakan hukum. Prasayarat tegaknya hukum, berarti undang-undang atau hukum harus memenuhi beberapa syarat seperti materi yang sesuai berupa syarat yuridis (legal), politik (legitimate), dan sosiologis (keberterimaan). Selain materi yang sesuai, tegaknya hukum memiliki syarat berfungsinya aparatur negara 
(Asshiddiqie, 2005). Metode analisis selanjutnya adalah metode SWOT. SWOT adalah sebuah akronim dari huruf awalnya yaitu Strength (kekuatan), Weaknesses (kelemahan), Opportunity (kesempatan) dan Threat (ancaman). Analisis ini akan mengevaluasi berbagai hal (Ward, 2002), termasuk asas dan tujuan undang-undang. Berdasarkan faktor SWOTnya, asas dan tujuan undang-undang kelautan dapat dievaluasi terhadap faktor yang menimbulkan kekuatan, kelemahan, peluang, dan ancaman.

Ilmu geodesi dan geomatika memiliki peran dalam implementasi undang-undang kelautan, hal ini diperjelas dalam naskah Undang-Undang No. 32 Tahun 2014 tentang Kelautan maupun Undang-Undang No. 4 Tahun 2011 tentang informasi geospasial. Dalam naskah akademik tersebut, geodesi dan geomatika diposisikan sebagai ilmu yang secara spesifik menekuni ilmu dan teknologi geospasial, informasi geospasial tersebut sangat berperan penting utamanya dalam penggambaran aset sumber daya kelautan. Keilmuan geodesi dan geomatika mempunyai empat macam bidang kajian yang berhubungan dengan laut. Keempat bidang tersebut mempunyai kontribusi yang penting dalam pembangunan kelautan (Windupranata, 1998).

Penelitian ini bertujuan untuk menganalisis asas dan tujuan undang-undang kelautan, serta sejauh mana asas dan tujuan tersebut dapat diimplementasikan di Indonesia. Selain itu, penelitian ini juga bertujuan mengidentifikasi sejauh mana peran dari keilmuan geodesi dan geomatika dapat mendukung implemetasi asas dan tujuan dari undang-undang kelautan. Batasan permasalahan dalam penelitian ini adalah: (1) analisis SWOT dan semantik bahasa yang dilakukan lebih ditekankan kepada analisis deskriptif yang independen yaitu penjabaran yang tidak memiliki korelasi satu dengan lainnya, (2) metode yuridis normatif berupa prasayarat tegaknya hukum hanya berdasarkan syarat sah dan absah dari materi hukumnya, tanpa melihat syarat-syarat yang lain, (3) peran keilmuan geodesi dan geomatika dibatasi pada empat bidang kajian yaitu, hidrografi, aspek-aspek geodetik dalam hukum laut (GALOS), geodesi kelautan dan sistem informasi kelautan.

\section{METODOLOGI}

Secara garis besar pelaksanaan penelitian dilakukan dengan alur seperti terlihat pada Gambar 1. Penelitian ini dilakukan beberapa tahapan kegiatan sebagai berikut:

\subsection{Proses Penjabaran Makna dari Asas dan Tujuan dalam Undang-Undang Kelautan}

Penjabaran makna dari asas dan tujuan dilakukan dengan menggunakan analisis semantik bahasa, hal ini dilakukan untuk mendapatkan gambaran besar dan pemaknaan yang mendalam terkait mimpi besar yang terkandung dalam undang-undang kelautan sehingga dapat diketahui kebutuhan apa saja yang diperlukan untuk mengimplementasikannya. Dalam menjabarkan makna dalam asas, dilakukan dengan menjabarkan makna sesuai dengan nama asas itu sendiri, beserta penjelasannya yang ada dalam undang-undang. Penjabaran tersebut digunakan untuk mencari fokus utama yang terkandung sehingga dapat kita simplifikasikan asas menjadi beberapa kelas. Sedangkan untuk penjabaran tujuan dilakukan dengan menjabarkan kata per kata beserta kalimat masing-masing tujuan yang tercantum dalam undang-undang, sehingga didapat penjabaran makna dari masing-masing tujuan beserta hal yang harus dilakukan atau dipenuhi dalam pegimplementasiannya dengan mempertimbangkan asas yang telah dikalsifikasikan sebelumnya. 


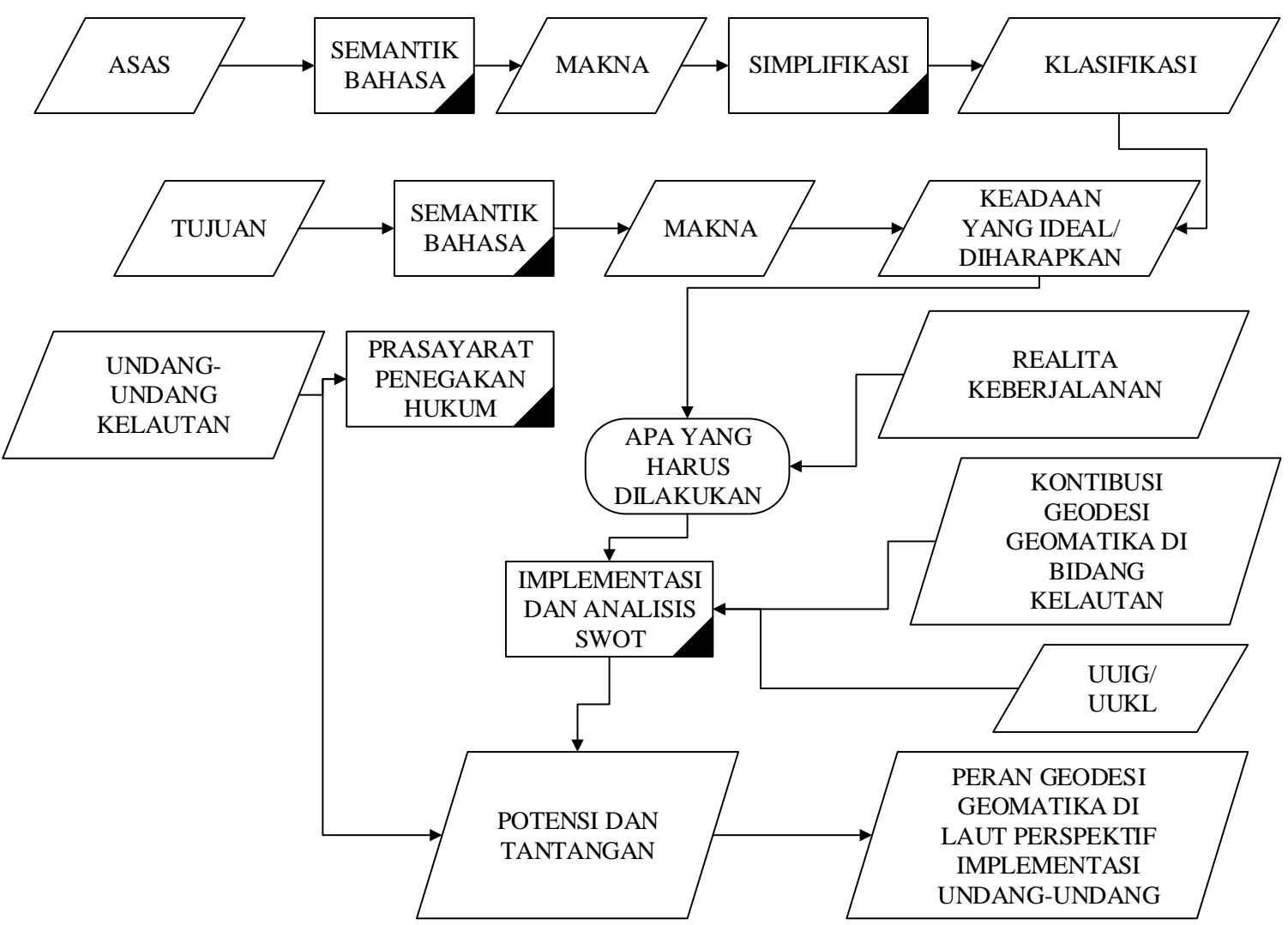

Gambar 1 Diagram Alir Penelitian

\subsection{Proses Analisis Implementasi Menggunakan Metode SWOT}

Hasil yang didapat pada penjabaran makna asas dan tujuan dianalisis menggunakan metode SWOT. Hasil analisis berupa deskripsi dari kekuatan, peluang, kelemahan, dan ancaman yang ada di sekitar usaha implementasi tujuan dan asas yang sudah dijabarkan sebelumnya

\subsection{Proses Analisis Impelementasi Undang-Undang dengan Prasyarat Tegak atau Terimplementasikannya Hukum dari Aspek Materi Hukum yang Sah dan Absah}

Untuk melihat apakah undang-undang kelautan secara hukum atau materi hukum memenuhi salah satu syarat implementasi, yaitu sah (legal) dan absah (legitimate). Undang-undang tersebut harus memenuhi syarat, yaitu norma hukum yang bersangkutan tidak bertentangan dengan norma yang lebih tinggi, norma hukum yang bersangkutan ditetapkan menurut prosedur yang sah dan ditetapkan oleh lembaga yang memang berwenang untuk itu, serta norma hukum yang bersangkutan mendapat dukungan opini publik atau wacana dominan dan juga mendapat dukungan mayoritas suara partai politik yang tercermin dalam suara mayoritas anggota parlemen.

\subsection{Proses Analisis Kontribusi Keilmuan Geodesi dan Geomatika Bidang Kelautan dalam Implementasinya Terhadap Undang-Undang Kelautan}

Kontribusi keilmuan geodesi dan geomatika di bidang kelautan kita lihat dari empat bidang kajian, yaitu: bidang hidrografi, bidang sistem informasi kelautan, bidang geodesi kelautan, dan bidang kajian aspek-aspek geodetik dalam hukum laut (Geodetic Aspects of the Law of the Sea/GALOS). Empat bidang ini selanjutnya dihubungkan dengan implementasi hasil pemaknaan tujuan dan asas. 


\section{HASIL DAN ANALISIS}

\subsection{Penjabaran Makna dari Asas dan Tujuan dalam Undang-Undang Kelautan}

Kesebelas asas dalam undang-undang kelautan diklasifikasikan berdasarkan fokus utamanya yang dilihat berdasarkan makna yang terkandung di dalamnya. Kesebelas asas dalam undang-undang kelautan diklasifikasikan menjadi tiga fokus utama, yaitu: instansi atau subjek, proses atau pengelolaan dan pemanfaatan kelautan, dan aturan atau hukum (Tabel 1).

Tabel 1 Makna, Fokus Utama, dan Klasifikasi Asas dalam Undang-Undang Kelautan

\begin{tabular}{|c|c|c|c|}
\hline No & Asas & $\begin{array}{l}\text { Fokus Utama dan Makna } \\
\end{array}$ & Klasifikasi \\
\hline 1 & Keberlanjutan & $\begin{array}{l}\text { Sumber daya kelautan yang tetap terjaga dengan (proses) } \\
\text { pemanfaatan sumber daya kelautan yang menggunakan } \\
\text { prinsip keberlanjutan. }\end{array}$ & Proses \\
\hline 2 & Konsistensi & $\begin{array}{l}\text { Konsistensi instansi (subjek) dalam penyelenggaraan sumber } \\
\text { daya kelautan. }\end{array}$ & Subjek \\
\hline 3 & Keterpaduan & Terpadunya kebijakan (aturan / hukum) kelautan. & Aturan/Hukum \\
\hline 4 & $\begin{array}{l}\text { Kepastian } \\
\text { Hukum }\end{array}$ & $\begin{array}{l}\text { Penyelenggaraan kelautan (proses) yang memiliki kepastian } \\
\text { hukum. }\end{array}$ & Proses \\
\hline 5 & Kemitraan & $\begin{array}{l}\text { Kemitraan dan kerja sama antara pihak-pihak (subjek) yang } \\
\text { berkepentingan. }\end{array}$ & Subjek \\
\hline 6 & Pemerataan & $\begin{array}{l}\text { Pemerataan dalam pemanfatan (proses) sumber daya } \\
\text { kelautan. }\end{array}$ & Proses \\
\hline 7 & $\begin{array}{l}\text { Peran serta } \\
\text { Masyarakat }\end{array}$ & $\begin{array}{l}\text { Penyelenggaraan kelautan (proses) yang mendorong peran } \\
\text { serta masyarakat. }\end{array}$ & Proses \\
\hline 8 & Keterbukaan & $\begin{array}{l}\text { Penyelenggaraan kelautan (proses) yang terbuka dan } \\
\text { menjalankan prinsip keterbukaan. }\end{array}$ & Proses \\
\hline 9 & Desentralisasi & $\begin{array}{l}\text { Pelimpahan dan desentralisasi kegiatan pemerintah (subjek) } \\
\text { kepada wakil pemerintah. }\end{array}$ & Subjek \\
\hline 10 & Akuntabilitas & $\begin{array}{l}\text { Penyelenggaraan kelautan (proses) yang memiliki dan } \\
\text { menerapkan prinsip akuntabilitas. }\end{array}$ & Proses \\
\hline 11 & Keadilan & $\begin{array}{l}\text { Materi muatan dari hukum (aturan) yang mencerminkan } \\
\text { prinsip keadilan. }\end{array}$ & Aturan/Hukum \\
\hline
\end{tabular}

Penjabaran makna tujuan dilakukan dengan mencari makna dalam tiap kalimat atau kata yang terkandung dalam masing-masing tujuan. Sehingga dalam delapan tujuan yang ada didapat penjabaran berupa implementasi (Tabel 2).

\subsection{Analisis Implementasi Menggunakan Metode SWOT}

Hasil dari implementasi tujuan yang berdasarkan asas tersebut dijabarkan kekuatan, kelemahan, peluang, dan ancaman di sekitar pengimplementasiannya (Tabel 3). Jika dilihat pada hasil analisis pada Tabel 3 dapat dikatakan hasilnya sangatlah beragam dan hampir beimbang antara kekuatan, kelemahan, kesempatan dan ancaman. Walaupun ada juga sebagian tujuanm yang memiliki sangat sedikit ancaman, akan tetapi hampir semua bagian pengimplementasian memiliki kekuatan. Beberapa poin yang merupakan kelemahan adalah berupa tidak adanya aturan yang mengatur suatu permasalahan tertentu, seperti kebijakan kelautan, tata ruang, budaya bahari dan lainnya, sehingga pengadaan aturan yang diperlukan menjadi salah satu yang utamanya harus dilakukan untuk membuat implementasi undang-undang kelautan menjadi lebih baik. 
Tabel 2. Implementasi Berdasarkan Tujuan dalam Undang-Undang Kelautan

\begin{tabular}{|c|c|c|}
\hline $\begin{array}{c}\text { Tujuan } \\
\text { ke }\end{array}$ & Implementasi & $\begin{array}{c}\text { Klasifikasi Asas } \\
\text { Terkait }\end{array}$ \\
\hline 1 & $\begin{array}{ll} & \text { Memperbaharui daftar penamaan dan perhitungan } \\
\text { Indonesia } & \text { pulau yang ada di Indonesia. Menjaga pulau-pulau } \\
\text { Negara } & \text { terdepan; Melakukan penegasan wilayah negara } \\
\text { Kepulauan; } & \text { kepulauan melalui penegasan batas-batas maritim di } \\
\text { Berciri } & \text { dalam maupun luar Indonesia; Mela-kukan penegasan } \\
\text { Maritim dan } & \text { wilayah negara ke-pulauan melalui penegasan batas- } \\
\text { Nusantara } & \begin{array}{l}\text { batas maritim di dalam maupun luar Indonesia; } \\
\end{array} \\
& \text { Membuat dan mengapli-kasikan konsepsi ciri maritim } \\
& \text { nasional } \\
\end{array}$ & $\begin{array}{l}\text { Subjek, Proses, } \\
\text { Aturan/Hukum }\end{array}$ \\
\hline 2 & $\begin{array}{l}\text { Meningkatkan pengetahuan dan keahlian dalam pendayagunaan } \\
\text { sumber daya kelautan dan kegiatan di wilayah laut; Melakukan } \\
\text { inventarisasi sumber daya kelautan, baik jumlah maupun posisinya; } \\
\text { Mengatur dengan sebaik-baiknya segala kegiatan pendayagunaan } \\
\text { dan kegiatan di wilayah laut dengan menerbitkan peraturan } \\
\text { perundang-undangan yang terkait, sehingga segala kegiatan dapat } \\
\text { menjadi pendukung untuk mewujudkan kemakmuran bangsa dan } \\
\text { negara. }\end{array}$ & $\begin{array}{l}\text { Subjek, Proses, } \\
\text { Aturan/Hukum }\end{array}$ \\
\hline 3 & $\begin{array}{l}\text { Melakukan pengelolaan ruang laut secara proporsional; Membangun } \\
\text { dan menjalankan sistem pertahanan dan keamanan laut; } \\
\text { Menjalankan pogram perlindungan lingkungan laut secara terpadu; } \\
\text { Menjadikan laut Indonesia sebagai ruang hidup dan ruang juang }\end{array}$ & $\begin{array}{l}\text { Subjek, Proses, } \\
\text { Aturan/Hukum }\end{array}$ \\
\hline 4 & $\begin{array}{l}\text { Meningkatkan pemahaman akan potensi dari segi jumlah,kapasitas, } \\
\text { posisi, jenis, hingga manfaat dari sumber daya kelautan yang ada di } \\
\text { wilayah laut Indonesia; Membuat kebijakan ekonomi yang } \\
\text { berkelanjutan dan berpihak pada kesejahteraan rakyat; Pengelolaan, } \\
\text { penjagaan dan pemanfaatan sumber daya kelautan secara bersama- } \\
\text { sama (pemerintah, daerah dan masyarakat) }\end{array}$ & $\begin{array}{l}\text { Subjek, Proses, } \\
\text { Aturan/Hukum }\end{array}$ \\
\hline 5 & $\begin{array}{l}\text { Melakukan inventarisasi budaya dan pengetahuan kelautan yang } \\
\text { dapat memberikan manfaat bagi masyarakat; Meningkatkan } \\
\text { pengetahuan kelautan dengan mendorong penelitian di bidang } \\
\text { kelautan; Mensosialisasikan dan menanamkan budaya dan } \\
\text { pengetahuan kelautan yang Pemerataan kepada masyarakat. }\end{array}$ & $\begin{array}{l}\text { Subjek, Proses, } \\
\text { Aturan/Hukum }\end{array}$ \\
\hline 6 & $\begin{array}{ll}\text { Melakukan } & \text { Ilmu, pengetahuan, dan teknologi kelautan } \\
\text { pengembangan } & \text { teoritis dan praktis; Pengembangan karakter } \\
\text { berupa pendidikan, } & \text { profesional, beretika, dan berdedikasi; } \\
\text { dan pelatihan } & \text { Wawasan kebangsaan yang menanamkan } \\
\text { sumber daya } & \text { kepentingan nasional dalam pelaksanaan } \\
\text { manusia yang sudah } & \text { kegiatan di wilayah kelautan, serta } \\
\text { atau akan terlibat di } & \text { pentingnya keterpaduan setiap ilmu dan } \\
\text { bidang kelautan. } & \text { pihak berwenang yang berhubungan dengan } \\
\end{array}$ & $\begin{array}{l}\text { Subjek, Proses, } \\
\text { Aturan/Hukum }\end{array}$ \\
\hline 7 & $\begin{array}{l}\text { Pembuatan hukum dan aturan yang jelas, tegas dan dapat } \\
\text { diimplementasikan terkait penyelenggaraan kelautan di Indonesia; } \\
\text { Memaksimalkan potensi Indonesia sebagai negara kepulauan; } \\
\text { Konsistensi dari pemerintah sebagai pelaksana dan penegak hukum } \\
\text { dalam pelaksanaan dan penegakkan hukum; Pengawasan dan } \\
\text { transparansi dalam proses pembuatan, penetapan, pelaksanaan, } \\
\text { dan penegakkan hukum. }\end{array}$ & $\begin{array}{l}\text { Subjek, Proses, } \\
\text { Aturan/Hukum }\end{array}$ \\
\hline 8 & $\begin{array}{l}\text { Meratifikasi hukum laut internasional yang belum dirtifikasi dan } \\
\text { sudah disepakati sebelumnya; Turut aktif dalam forum Internasional; } \\
\text { Menjaga keamanan dan keselamatan laut di wilayah perairan dan } \\
\text { yuridiksi maupun laut lepas. }\end{array}$ & $\begin{array}{l}\text { Subjek, Proses, } \\
\text { Aturan/Hukum }\end{array}$ \\
\hline
\end{tabular}


Tabel 3 Analisis SWOT pada Implementasi Undang-Undang

\begin{tabular}{|c|c|c|c|c|}
\hline $\begin{array}{c}\text { Tujuan } \\
\text { ke }\end{array}$ & Strengths & Weakness & Oportunities & Threats \\
\hline 1 & $\begin{array}{l}\text { Memiliki banyak } \\
\text { pulau juga lautan } \\
\text { yang luas; Memiliki } \\
\text { ciri-ciri fisik sebagai } \\
\text { negara maritim; } \\
\text { Konsespsi } \\
\text { kemaritiman dan } \\
\text { kenusantaraan } \\
\text { cukup dipahami elit } \\
\text { pemegang } \\
\text { kekuasaan; Konsepsi } \\
\text { kemaritiman dan } \\
\text { kenusantaraan } \\
\text { sudah masuk dalam } \\
\text { kebijakan } \\
\text { pembangunan dan } \\
\text { pemerintahan; } \\
\text { contoh: RPJP 2005- } \\
\text { 2025 }\end{array}$ & $\begin{array}{l}\text { Belum memiliki } \\
\text { konsepsi Kemaritiman } \\
\text { berupa dokumen resmi } \\
\text { negara; } \\
\text { Belum memiliki } \\
\text { konsepsi } \\
\text { Kenusantaraan berupa } \\
\text { dokumen resmi } \\
\text { negara; } \\
\text { Konsespsi kemaritiman } \\
\text { dan kenusantaraan } \\
\text { belum dipahami } \\
\text { masyarakat awam; } \\
\text { Belum ada UU tentang } \\
\text { Zona Tambahan dan } \\
\text { revisi UU Landas } \\
\text { Kontinen; Batas } \\
\text { wilayah antar daerah } \\
\text { belum selesai }\end{array}$ & $\begin{array}{l}\text { Sudah } \\
\text { mendaftarkan } \\
13.466 \text { pulau ke } \\
\text { PBB; Sudah diakui } \\
\text { sebagai negara } \\
\text { kepulauan; Salah } \\
\text { satu alur pelayaran } \\
\text { utama dunia }\end{array}$ & $\begin{array}{l}\text { Belum } \\
\text { mendaftarkan } \\
\text { ribuan pulau ke } \\
\text { PBB } \\
\text { Ada batas dengan } \\
\text { negara tetangga } \\
\text { yang belum tegas } \\
\text { (belum } \\
\text { dirundingkan, } \\
\text { sedang } \\
\text { dirundingkan, } \\
\text { atau ditetapkan } \\
\text { tapi belum } \\
\text { diratifikasi) }\end{array}$ \\
\hline 2 & $\begin{array}{l}\text { Memiliki sumber } \\
\text { daya kelautan yang } \\
\text { melimpah; } \\
\text { Adanya pemerataan } \\
\text { dana alokasi daerah } \\
\text { pesisir; } \\
\text { Adanya informasi } \\
\text { sumberdaya } \\
\text { kelautan yang } \\
\text { didapat dari } \\
\text { berbagai bidang } \\
\text { ilmu. }\end{array}$ & $\begin{array}{l}\text { Pendapatan dari } \\
\text { Sumber Daya Kelautan } \\
\text { belum maksimal; } \\
\text { Belum ada aturan } \\
\text { mengenai bangunan } \\
\text { laut; Belum ada aturan } \\
\text { industri dan jasa } \\
\text { maritim; Belum ada } \\
\text { aturan kebijakan } \\
\text { budaya bahari; } \\
\text { Informasi sumber daya } \\
\text { kelautan belum } \\
\text { terpadu dan belum } \\
\text { mudah diakses. }\end{array}$ & $\begin{array}{l}\text { Telah } \\
\text { menadatangani dan } \\
\text { meratifikasi } \\
\text { UNCLOS } 82\end{array}$ & \\
\hline 3 & $\begin{array}{l}\text { Mempunyai sarana } \\
\text { kapal perang yang } \\
\text { cukup memadai; } \\
\text { Mempunyai laut } \\
\text { yang luas dan } \\
\text { berpotensi menjadi } \\
\text { ruang hidup dan } \\
\text { juang. }\end{array}$ & $\begin{array}{l}\text { Kapal patroli keamanan } \\
\text { (BAKAMLA) yang masih } \\
\text { kurang memadai; } \\
\text { Sistem } \\
\text { penanggulangan } \\
\text { bencana laut yang } \\
\text { belum terpadu; Belum } \\
\text { mempunyai wahana } \\
\text { satelit pribadi yang } \\
\text { akan menjadi potensi } \\
\text { ancaman dalam } \\
\text { pertahanan; Sistem } \\
\text { keamanan yang belum } \\
\text { terpadu; Belum adanya } \\
\text { kebija-kan tata ruang } \\
\text { laut }\end{array}$ & $\begin{array}{l}\text { Kerjasama dalam } \\
\text { hal keamanan laut } \\
\text { dengan negara } \\
\text { tetangga terkait } \\
\text { kebencanaan; } \\
\text { Kerjasama terkait } \\
\text { kemananan, } \\
\text { khususnya di } \\
\text { wilayah laut bebas }\end{array}$ & $\begin{array}{l}\text { Indonesia sebagai } \\
\text { salah satu alur } \\
\text { pelayaran utama } \\
\text { rawan dalam } \\
\text { keamanan dan } \\
\text { pertahanan }\end{array}$ \\
\hline
\end{tabular}


Tabel 3 Analisis SWOT pada Implementasi Undang-Undang (Lanjutan)

\begin{tabular}{|c|c|c|c|c|}
\hline 4 & $\begin{array}{l}\text { Memiliki potensi } \\
\text { sumber daya } \\
\text { kelautan (perikanan, } \\
\text { energi dan sumber } \\
\text { daya mineral, } \\
\text { sumber daya pesisir } \\
\text { dan pulau, dan } \\
\text { sumber daya non } \\
\text { konvensional yang } \\
\text { melimpah }\end{array}$ & $\begin{array}{l}\text { Belum adanya } \\
\text { kebijakan ekonomi } \\
\text { kelautan yang terpadu } \\
\text { dan berkeadilan }\end{array}$ & $\begin{array}{l}\text { Bekerasama } \\
\text { dengan pihak asing } \\
\text { dengan perjanjian } \\
\text { yang } \\
\text { menguntungkan } \\
\text { kedua pihak secara } \\
\text { proporsional }\end{array}$ & $\begin{array}{l}\text { Pihak asing yang } \\
\text { tidak } \\
\text { bertanggungjawab } \\
\text { dalam mengelola } \\
\text { sumber daya } \\
\text { kelautan }\end{array}$ \\
\hline 5 & $\begin{array}{l}\text { Memiliki budaya } \\
\text { bahari yang } \\
\text { beragam dan } \\
\text { beberapa masih } \\
\text { terjaga dengan baik; } \\
\text { Tersedia laut yang } \\
\text { lengkap kekayaan } \\
\text { alamnya sebagai } \\
\text { tempat penelitian } \\
\text {;Sumberdaya } \\
\text { manusia yang dapat } \\
\text { diandalkan. }\end{array}$ & $\begin{array}{l}\text { Belum ada inventarisasi } \\
\text { budaya bahari yang } \\
\text { lengkap dan dapat } \\
\text { diakses dengan } \\
\text { mudah; } \\
\text { Belum ada kebijakan } \\
\text { budaya bahari; Belum } \\
\text { ada kebijakan tentang } \\
\text { pusat fasilitas kelautan } \\
\text { daerah yang meliputi } \\
\text { falisitas pendidikan, } \\
\text { pelatihan, penelitian; } \\
\text { Dana penelitian yang } \\
\text { kurang diprioritaskan } \\
\text { dan dipermudah }\end{array}$ & $\begin{array}{l}\text { Melakukan kerja } \\
\text { sama dengan pihak } \\
\text { asing terkait } \\
\text { penelitian laut }\end{array}$ & $\begin{array}{l}\text { Besarnya } \\
\text { pengaruh budaya } \\
\text { asing yang dapat } \\
\text { menyamarkan } \\
\text { budaya Indonesia }\end{array}$ \\
\hline 6 & $\begin{array}{l}\text { Sumber daya } \\
\text { manusia yang } \\
\text { unggul dalam bidang } \\
\text { ilmu pengetahuan } \\
\text { dan kecerdasan; } \\
\text { Melimpahnya } \\
\text { makanan bergizi } \\
\text { yang dapat } \\
\text { menunjang kapasitas } \\
\text { SDM. }\end{array}$ & $\begin{array}{l}\text { Sistem pendidikan } \\
\text { nasional yang belum } \\
\text { memfasilitasi wawasan } \\
\text { nusantara dan maritim } \\
\text { dengan proporsional; } \\
\text { Pengembangan } \\
\text { karakter ke generasi } \\
\text { muda yang masih } \\
\text { menjadi tantangan } \\
\text { sulit; Kurangnya materi } \\
\text { atau pengkondisian } \\
\text { akan Pentingnya } \\
\text { mendahulukan } \\
\text { kepentingan nasional. }\end{array}$ & $\begin{array}{l}\text { Kerjasama dalam } \\
\text { bidang pendidikan } \\
\text { dan pelatihan } \\
\text { sumber daya } \\
\text { manusia. }\end{array}$ & $\begin{array}{l}\text { SDM profesional } \\
\text { asing yang } \\
\text { berdatangan } \\
\text { dengan semakin } \\
\text { bebasnya arus } \\
\text { globalisasi. }\end{array}$ \\
\hline 7 & $\begin{array}{l}\text { Dasar negera yang } \\
\text { mementingkan } \\
\text { kesejahteraan rakyat } \\
\text { dan negara. }\end{array}$ & $\begin{array}{l}\text { Belum ada aturan } \\
\text { tentang penjelasan } \\
\text { penyelenggaraan } \\
\text { kelautan di idonesia; } \\
\text { Penegak hukum yang } \\
\text { masih belum bersih } \\
\text { dan transparan dalam } \\
\text { proses penegakan } \\
\text { hukum; Masih ada } \\
\text { hukum atau aturan } \\
\text { yang tumpang tindih. }\end{array}$ & $\begin{array}{l}\text { Partisipasi aktif } \\
\text { dalam forum } \\
\text { hukum laut } \\
\text { dunia;Pengakuan } \\
\text { dunia atas } \\
\text { kedaulatan } \\
\text { Indonesia secara } \\
\text { de jure. }\end{array}$ & $\begin{array}{l}\text { Pemanfaatan } \\
\text { sumber daya laut } \\
\text { yang tidak sesuai } \\
\text { dengan prinsip } \\
\text { keadilan dan } \\
\text { pemerataan } \\
\text { manfaat bila tidak } \\
\text { diatur dengan } \\
\text { baik. }\end{array}$ \\
\hline
\end{tabular}


Tabel 3 Analisis SWOT pada Implementasi Undang-Undang (Lanjutan)

\begin{tabular}{lllll}
\hline & Dasar negera yang & Ada hukum atau & Partisipasi aktif & Keadaan politik di \\
memperhatikan & perjajian internasional & dalam forum & lautan yang \\
perdamaian dunia; & yang belum diratifikasi; & hukum laut dunia; & sedang dan \\
Penggagas gerakan & Perlengkapan dan & Pengakuan dunia & seringkali \\
& non blok dan bebas & sarana militer yang & atas kedaulatan & memanas \\
aktif; Sudah & belum memadai untuk & Indonesia secara & \\
diratifikasinya & turut menjaga & de jure & \\
sebagian besar & keamanan dunia & & \\
perjanjian & & & \\
internasional & & & \\
\hline
\end{tabular}

\subsection{Analisis Implementasi Undang-Undang dengan Prasyarat Tegak atau Terimplementasikannya Hukum dari Aspek Materi Hukum yang Sah (Lega) dan Absah (Legitimate)}

Untuk melihat apakah undang-undang kelautan secara hukum atau materi hukum memenuhi salah satu syarat implementasi, yaitu sah (legal) dan absah (legitimate). Undang-undang tersebut harus memenuhi syarat, yaitu:

1) Norma hukum yang bersangkutan tidak bertentangan dengan norma yang lebih tinggi. Di dalam undang-undang kelautan terdapat dasar hukum yang menyebutkan "Mengingat : Pasal 20, Pasal 22D ayat (1), Pasal 25A, dan Pasal 33 ayat (3) Undang-Undang Dasar Ncgara Republik Indonesia Tahun 1945". Dasar hukum tersebut (Pasal 20, Pasal 22D ayat (1)) menunjukkan pembentukan undang-undang yang berasal dari DPR atas usul DPD. Sedangkan pasal lainnya (Pasal 25A, dan Pasal 33 ayat (3)) berarti undang-undang yang akan dibentuk merupakan penjabaran dari pasal atau beberapa pasal undangundang dasar Negara Republik Indonesia tahun 1945. Berdasarkan dua hal tersebut, dapat dikatakan bahwa secara substansi dasar, undang-undang kelautan tidak bertentangan dengan norma yang lebih tinggi.

2) Norma hukum yang bersangkutan ditetapkan menurut prosedur yang sah dan ditetapkan oleh lembaga yang memang berwenang untuk itu. Secara garis besar proses pembentukan undang-undang terbagi menjadi 5 (lima) tahap, yakni perencanaan, penyusunan, pembahasan, pengesahan dan pengundangan (Kemenkumham, 2015). Perencanaan adalah tahap dimana DPR dan Presiden (serta DPD terkait Rancangan Undang-Undang (RUU) tertentu) menyusun daftar RUU yang akan disusun ke depan. Proses ini umumnya kenal dengan istilah penyusunan Program Legislasi Nasional (Prolegnas). Hasil pembahasan tersebut kemudian dituangkan dalam Keputusan DPR. Tahap Penyusunan RUU merupakan tahap penyiapan sebelum sebuah RUU dibahas bersama antara DPR dan Pemerintah, yang terdiri dari pembuatan naskah akademik, naskah RUU, dan harmonisasi, pembulatan, dan pemantapan konsepsi. Pembahasan materi RUU antara DPR dan Presiden ( dengan DPD untuk topik-topik tertentu) melalui 2 tingkat pembicaraan. Tingkat 1 adalah pembicaraan dalam rapat komisi, rapat gabungan komisi, rapat badan legislasi, rapat badan anggaran atau rapat panitia khusus. Tingkat 2 adalah pembicaraan dalam rapat paripurna. Setelah ada persetujuan bersama antara DPR dan Presiden terkait RUU yang dibahas bersama, Presiden mengesahkan RUU tersebut dengan cara membubuhkan tanda tangan pada naskah RUU. Lalu tahap akhirnya adalah pengundangan atau penempatan UU yang telah disahkan ke dalam Lembaran Negara (LN), yakni untuk batang tubung UU, dan Tambahan Lembaran Negara (TLN) yakni jika ada penjelasan UU dan lampirannya. Dalam keberjalannya undang-undang kelautan telah melewati semua proses tersebut, sehingga memenuhi syarat prosedur yang sah dan ditetapkan oleh lembaga yang berwenang. 
3) Norma hukum yang bersangkutan mendapat dukungan opini publik atau wacana dominan dan juga mendapat dukungan mayoritas suara partai politik yang tercermin dalam suara mayoritas anggota parlemen. Disahkannya undang-undang kelautan mendapat respon dari masyarakat dengan adanya pemberitaan di beberapa media nasional dan juga pendapat dari berbagai kalangan, walaupun tidak semua kalangan menyembutnya dengan positif. Selain itu dalam rapat pleno badan legislatif DPR, mayoritas fraksi menerima RUU Kelautan (DPR-RI, 2015). Sehingga undang-undang kelautan juga memenuhi syarat dukungan opini publik dan mayoritas suara partai politik.

\subsection{Kontribusi Keilmuan Geodesi dan Geomatika Bidang Kelautan Dalam Implementasinya Terhadap Undang-Undang Kelautan}

Dalam implementasi undang-undang kelautan, sesuai dengan naskah akademik undangundang kelautan, keilmuan geodesi dan geomatika sebagai penyedia data informasi geospasial banyak berperan dalam memberikan informasi yang berhubungan dengan keruangan dan berperan sebagai pemberi gambaran (yang utamanya posisi atau sebaran) akan aset-aset yang dimiliki wilayah laut Indonesia (Tabel 4).

Tabel 4 Kontribusi Keilmuan Geodesi dan Geomatika

\begin{tabular}{|c|c|c|c|}
\hline $\begin{array}{c}\text { Tujuan } \\
\text { ke }\end{array}$ & & Implementasi & Kontirbusi Keilmuan Geodesi \\
\hline 1 & $\begin{array}{l}\text { Indonesia } \\
\text { Negara } \\
\text { Kepulauan; } \\
\text { Berciri } \\
\text { Maritim } \\
\text { dan } \\
\text { Nusantara }\end{array}$ & $\begin{array}{l}\text { Memperbaharui daftar penamaan dan } \\
\text { perhitungan pulau yang ada di Indonesia. } \\
\text { Serta menjaga pulau-pulau terdepan; } \\
\text { Melakukan penegasan wilayah negara } \\
\text { kepulauan melalui penegasan batas-batas } \\
\text { maritim di dalam maupun luar Indonesia; } \\
\text { Melakukan penegasan wilayah negara } \\
\text { kepulauan melalui penegasan batas-batas } \\
\text { maritim di dalam maupun luar Indonesia; } \\
\text { Membuat dan mengaplikasikan konsepsi } \\
\text { ciri maritim nasional }\end{array}$ & $\begin{array}{l}\text { Penyedia Data Spasial; } \\
\text { Mengembangkan Sistem } \\
\text { Informasi Kepulauan; Penyedia } \\
\text { data dan informasi batas } \\
\text { maritim; Penetapan titik pangkal } \\
\text { dan batas negara di laut; } \\
\text { Mengembangkan Sistem } \\
\text { Informasi Batas MartitimKalibrasi } \\
\text { alat navigasi dan survey laut; } \\
\text { Penyedia Data Ciri Fisik / Alam } \\
\text { Laut; Sebagai Sumber Informasi } \\
\text { kelautan ; Penegasan Batas } \\
\text { Maritim; Memodelkan ciri fisis } \\
\text { maritim Indonesia }\end{array}$ \\
\hline 2 & \multicolumn{2}{|c|}{$\begin{array}{l}\text { Meningkatkan pengetahuan dan keahlian dalam } \\
\text { pendayagunaan sumber daya kelautan dan kegiatan di } \\
\text { wilayah laut; Melakukan inventarisasi sumber daya } \\
\text { kelautan, baik jumlah maupun posisinya; Mengatur } \\
\text { dengan sebaik-baiknya segala kegiatan pendayagunaan } \\
\text { dan kegiatan di wilayah laut dengan menerbitkan } \\
\text { peraturan perundang-undangan yang terkait, sehingga } \\
\text { segala kegiatan dapat menjadi pendukung untuk } \\
\text { mewujudkan kemakmuran bangsa dan negara. }\end{array}$} & $\begin{array}{l}\text { Sebagai Penyedia Data Spasial } \\
\text { dan Fisik Laut; Sebagai Sumber } \\
\text { Informasi Kelautan; } \\
\text { Mengembangkan Sistem } \\
\text { Informasi Sumber Daya } \\
\text { Kelautan; Penentuan batas } \\
\text { wilayah sumber daya kelautan; } \\
\text { Meningkatkan akurasi } \\
\text { pemetaan.Subjek, Proses, } \\
\text { Aturan/Hukum }\end{array}$ \\
\hline
\end{tabular}


Tabel 4 Kontribusi Keilmuan Geodesi dan Geomatika (Lanjutan)

Melakukan pengelolaan ruang laut secara proporsional; Membangun dan menjalankan sistem pertahanan dan keamanan laut; Menjalankan pogram perlindungan lingkungan laut secara terpadu; Menjadikan laut Indonesia sebagai ruang hidup dan ruang juang
Sebagai Penyedia Data Spasial dan Fisik Laut; Mengembangkan Sistem Informasi Ruang Laut; Penentuan dan pembagian ruang laut; Meningkatkan akurasi pemetaan, dan kalibrasi peralatan; Mengembangkan Sistem Informasi Pertahanan dan Keamanan Laut; Penetapan Batas Maritim dan Wilayah wewenang; Survey Bencana; Sebagai Sumber Informasi kelautan

Meningkatkan pemahaman akan potensi dari segi jumlah,kapasitas, posisi, jenis, hingga manfaat dari sumber daya kelautan yang ada di wilayah laut Indonesia; Membuat kebijakan ekonomi yang berkelanjutan dan berpihak pada kesejahteraan rakyat; Pengelolaan, penjagaan dan pemanfaatan sumber daya kelautan secara bersama-sama (pemerintah, daerah dan masyarakat)

Melakukan inventarisasi budaya dan pengetahuan kelautan yang dapat memberikan manfaat bagi masyarakat; Meningkatkan pengetahuan kelautan

5 dengan mendorong penelitian di bidang kelautan; Mensosialisasikan dan menanamkan budaya dan pengetahuan kelautan yang Pemerataan kepada masyarakat.

\begin{tabular}{lll}
\hline & & Ilmu, pengetahuan, dan \\
teknologi kelautan teoritis dan \\
praktis; Pengembangan karakter
\end{tabular}

Pembuatan hukum dan aturan yang jelas, tegas dan dapat diimplementasikan terkait penyelenggaraan kelautan di Indonesia; Memaksimalkan potensi Indonesia sebagai negara kepulauan; Konsistensi dari pemerintah sebagai pelaksana dan penegak hukum dalam pelaksanaan dan penegakkan hukum; Pengawasan dan transparansi dalam proses pembuatan, penetapan, pelaksanaan, dan penegakkan hukum.
Penyedia Peta Laut dan Data Fisik Laut; Penetapan Batas Maritim dan Wilayah Wewenang; Sebagai Sumber Informasi Kelautan; Penyedia data Spasial untuk Sumber Daya Kelautan; Penetapan Batas Daerah

\section{Pengembangan Sistem} Informasi Kebudayaan Bahari; Penentuan bentuk fisis lautan dan gaya beratnya Sebagai Penyedia Data Spasial dan Fisik Laut; Sebagai Sumber Informasi Kelautan; Penetapan Geoid atau Mean Sea Level. Survey dan Pemetaan Laut; Pengembangan Sistem Informasi Kelautan; Survey dan Penentapan Batas Maritim; Pelatihan survey; Penentuan dan Penegasan Batas Maritim Wilayah Kedaulatan dan Yuridiksi Indonesia.
Memberikan pemahaman keadaan laut; Penyedia Sistem Informasi Kelautan; Penentuan dan Penegasan Batas Maritim Wilayah Indonesia; Memberikan kepastian batas dan kewenangan hukum Peta laut sebagai Pendukung Penegakan Hukum di Laut. 
Agung P. Nugroho, Eka Djunarsjah, Wiwin Windupranata

Tabel 4 Kontribusi Keilmuan Geodesi dan Geomatika (Lanjutan)

Meratifikasi hukum laut internasional yang belum dirtifikasi dan sudah disepakati sebelumnya; Turut aktif

8 dalam forum Internasional; Menjaga keamanan dan

keselamatan laut di wilayah perairan dan yuridiksi maupun laut lepas.
Pengembangan Sistem

Informasi Hukum Laut; Sebagai

Sumber Informasi kelautan;

Penelitian laut global; Penetapan titik pangkal dan batas negara di laut; Pengembangan Sistem Informasi Teritorial.

Keilmuan geodesi dan geomatika dapat memberikan beberapa kontribusi bahkan tidak jarang menjadi kontribusi pokok yang harus ada untuk mengimplementasikan hal-hal di atas. Beberapa hal pokok seperti penetapan batas maritim, penggambaran dasar laut dan muka laut rata-rata, juga peta yang dapat digunakan untuk navigasi perairan yang dapat membantu pekerjaan penelitian, penjagaan keamanan, pertahanan, wisata, perikanan, pelayaran, perlindungan ruang laut, sampai penataan ruang laut. Ada juga beberapa hal yang bukan hal pokok tetapi sangat membantu dalam pengimplementasian undang-undang ini, seperti contohnya sistem informasi kelautan (yang dapat dikembangkan menjadi sistem informasi kelautan tematik seperti sistem informasi kepulauan, sistem informasi perikanan, sistem informasi wisata bahari, sistem informasi kebencanaan laut, sistem informasi pertahanan laut, sistem informasi keamanan laut dan lain-lain) yang akan sangat membantu dalam pengambilan keputusan atau pembuatan kebijakan kelautan, karena dapat memberikan informasi yang beragam dengan cepat dan tepat.

\section{KESIMPULAN DAN SARAN}

Beberapa kesimpulan dan saran dari penelitian ini adalah: (1) analisis asas dapat dilakukan dengan pendekatan semantik. Asas dalam undang-undang kelautan berdasarkan pemaknaan dari penjelasan yang ada di dalam undang-undang dapat diklasifikasikan menjadi tiga fokus utama, yaitu subjek, proses/pengelolaan laut, dan hukum/aturan. Analisis dengan menggunakan pendekatan semantik bahasa pada tujuan dapat dilakukan dan menghasilkan beberapa kondisi ideal kelautan Indoensia. Dalam pelaksanaan pendekatan semantik terdapat beberapa tantangan dikarenakan ada beberapa istilah-istilah yang tidak umum yang digunakan dalam penulisan dan penjabaran asas maupun tujuan dalam undang-undang; (2) secara metode yuridis kalau kita lihat dari aspek sah (legal) dan absah (legitimation) maka undang-undang kelautan telah memenuhi kedua aspek tersebut, dengan prosesnya yang sesuai prosedur, dan hasilnya yang mendapat dukungan partai pilitik dan opini publik. Sehingga secara materi muatan, bisa dikatakan sudah memenuhi syarat akan bisa diimplementasikan; (3) berdasarkan analisis asas dan tujuannya menggunakan metode SWOT dan semantik bahasa, dapat disimpulkan bahwa dengan segala potensi yang ada di Indonesia, undang-undang akan dapat diimplementasikan dengan baik jika pemerintah segera menindaklanjuti pembuatan peraturan penjelas sesuai amanah undang-undang kelautan. Selain juga ada beberapa faktor seperti konsistensi pemerintah dalam menjalankan amanat lainnya di dalam undang-undang; (4)dalam pengimplementasian undang-undang kelautan. Peran keilmuan geodesi yang pada penelitian ini diwakili oleh empat bidang kajian, memiliki peran yang sangat besar. Setiap bidang kajian memiliki perannya masing-masing dalam proses penyelenggaraan kelautan Indonesia. Peran tersebut, mulai dari hal yang pokok seperti penyediaan peta navigasi dan peta lainnya, juga penentian batas maritim di dalam maupun luar negeri, hingga hal yang bisa jadi bukan pokok tetapi sangat membantu pelaksanaannya seperti pembuatan sistem informasi kelautan dasar maupun tematik. Kedepannya dapat dilakukan analisis korelasi yang tidak independen, salah satunya dengan cara menghubungkan antara variabel (antar asas, antar tujuan, maupun antara asas dan 
tujuan); (5) perlu dilakukan analisis implementasi undang-undang dari aspek yuridis secara utuh dengan mamsukkan aspek instansi dan sosiologis sehingga yang akan mampu melihat prasyarat pengimplementasian dengan lebih komprehensif; (6) perlu dilakukan evaluasi dan penelitan lanjutan bila nanti sudah dibuat aturan-aturan yang sesuai dengan amanah undang-undang ini, apakah akan semakin mudah atau ternyata semakin sulit untuk diimplementasikan; (7) penelitian dapat dikembangkan dengan lebih memfokuskan kajian implementasi dibeberapa bidang agar kajian lebih mendalam; (8) perlu dilakukan penelitian kontribusi geodesi dan geomatika dengan bidang kajian yang lebih luas seperti bidang, pengindraan jauh, kadaster, satelit, sistem informasi geografis (SIG), dan sebagainya sehingga akan dapat melihat lebih jauh kontribusi keilmuan geodesi dari sudut pandang undang-undang kelautan; (9) penelitian kontribusi geodesi dan geomatika juga dapat diperdalam ke beberapa bidang kelautan saja untuk membuat pembahasan lebih mendetail.

\section{DAFTAR PUSTAKA}

Asshiddiqie, J. (2005). Negara Hukum Indonesia: Paradigma Penyelenggaraan negara dan pembangunan nasional berwawasan hukum. Jakarta

Dahuri, R. (2015a). Industri Bioteknologi Kelautan Sebagai Mesin Pertumbuhan Ekonomi Baru Indonesia. Dipetik Agustus, 2015 dari http://rokhmindahuri.info/2012/10/09 /industri-bioteknologi-kelautan-sebagai-mesin-pertumbuhan-ekonomi-baru-indonesia2/.

Dahuri, R. (2015b). Kuliah umum jurusan perikanan universitas gajah mada: Industrialisasi Perikanan Berbasis Sumberdaya Maritim. Dipetik Agustus 2015, dari http://ugm.ac.id/id/berita/9256potensi.kelautan.indonesia.12.triliun.belum.digarap.maksimal.

DPD RI. (2015). Komite II DPD Menggambarkan Arsitektur Hukum di Bidang Kelautan. Dipetik September, 2015 dari http://www.dpd.go.id/artikel-komite-ii-dpdmenggambarkan-arsitektur-hukum-di-bidang-kelautan.

Kemenkumham. (2015). Proses Pembentukan Undang-Undang dalam Direktorat jenderal peraturan perundang-undangan kementrian hukum dan hak asasi manusia Republik Indonesia. Dipetik September, 2015 dari http://peraturan.go.id/welcome/index/prolegnas_pengantar.html.

Pemerintah Indonesia. (2014). Undang-undang Republik Indonesia no 32 tahun 2014 tentang Kelautan.

Ward, J. dan Peppard, J. (2002). Strategic Planning for Information Systems. 3 ed., John Wiley \& Sons, 2002.

Windupranata, W. (1998). Kontribusi Geodesi Kelautan dalam Aktualisasi Benua Maritim Indonesia. Tugas Akhir. Bandung: ITB. 